\title{
Cognitive Deterioration Following Strength Training in Adolescents
}

\section{Kuvvet Antrenmanı Sonrası Adolesanlarda Bilişsel Işlevlerde Bozulma}

Melda Pelin Yargic ${ }^{1}$,

Leyla Aydin²,

Kenan Erdagi ${ }^{3}$,

Erhan Kiziltan ${ }^{4}$

${ }^{1}$ Necmettin Erbakan University, Meram Faculty of Medicine, Department of Sports Medicine, Konya, Turkey

${ }^{2}$ Necmettin Erbakan University, Meram

Faculty of Medicine, Department of

Physiology, Konya, Turkey

${ }^{3}$ Necmettin Erbakan University, Ahmet

Kelesoglu Faculty of Education, Department

of Physical Education and Sports, Konya, Turkey

${ }^{4}$ Baskent University, Faculty of Medicine,

Department of Biophysics, Ankara, Turkey

Geliş Tarihi/Received: 24 July 2019

Kabul Tarihi/Accepted: 20 January 2020

Address correspondence to: Melda Pelin Yargic, Necmettin Erbakan University, Meram Faculty of Medicine, Department of Sports Medicine, Konya, Turkey

e-mail:meldapelin@gmail.com

\section{ORCID}

Melda Pelin Yargic

https://orcid.org/0000-0003-4487-5602

Leyla Aydin

https://orcid.org/0000-0001-8771-5030

Kenan Erdagi

https://orcid.org/0000-0002-2338-6546

Erhan Kiziltan

https://orcid.org/0000-0001-6029-3835

\begin{abstract}
Öz
Amaç: Çalışmalar düzenli aerobik egzersizin dikkat, yürütücü işlevler, hafıza ve işleme hızı gibi bilişsel fonksiyonların çeşitli yönlerini geliştirdiğini göstermiştir. Ancak, elit düzeyde kuvvet egzersizinin ergenlik döneminde bilişsel işlevi nasıl etkilediği açık değildir. Bu çalışmanın amacı, yüksek antrenmanlı adolesanlarda tek seans kuvvet egzersizinin bilişsel fonksiyonları nasıl etkilediğini tespit etmektir.

Hastalar ve Yöntem: Yirmi beş elit kadın adolesan haltercinin motor becerileri, dikkati sürdürme ve yürütme fonskiyonları parmak vuru testi (PVT), basit-görsel reaksiyon zamanı (B-GRZ), kompleks-görsel reaksiyon zamanı (K-GRZ), basit tanıma-görsel reaksiyon zamanı (BT-GRZ) ve kompleks tanıma-görsel reaksiyon zamanı (KT-GRZ) testleri ile değerlendirilmiştir. Haltercilere testler antrenman seansı öncesinde ve sonrasında uygulanmıştır. Ölçümler 2019 yılında gerçekleştirilmiştir.

Bulgular: Egzersiz sonrası haltercilerin ortalama KT-GRZ süresinde belirgin uzama görülmüştür $(p<0.01)$. BT-GRZ ile KT-GRZ testlerinde ise yanlış cevap oranlarında anlamlı artış olmuştur (sırasıyla $p<0.01$ ve $p<0.05$ ). Egzersiz öncesi ve sonrasında parmak vuru sayısı ve vurular arası sürede anlamlı bir farklılık görülmemiştir $(p>.05)$.

Sonuç: Elit adolesan kadın haltercilerde tek seanslık kuvvet egzersizi sonrası bilişsel fonksiyonlar bozulmaktadır. Gelecek çalışmalarda halter antrenmanının oluşturduğu bu bozucu etkinin ne kadar süre boyunca etkili olduğunun araştırılması uygun olacaktır.
\end{abstract}

Anahtar Kelimeler: Bilişşel işlev, yürütücü işlev, reaksiyon zamanı, halter, ergen

\section{Abstract}

Aim: Studies have demonstrated that regular aerobic exercise improves several aspects of cognition such as attention, executive functions, memory and processing speed. However, it is not clear how elite-level strength training affects cognitive function during adolescence. The aim of this study was to determine how a single session of strength training affects cognition in highly trained adolescents.

Patients and Methods: Motor functions, ability of sustaining attention and executive functions of 25 elite female adolescent weightlifters were evaluated through finger tapping performance, simple visual reaction time (S- VRT), complex visual reaction time (C-VRT), simple recognition visual reaction time (SR-VRT) and complex recognition visual reaction time (CR-VRT) tests. Weightlifters were tested before and after a training session. Tests were performed in 2019.

Results: There was a significant increase in mean CR-VRT of weightlifters after training $(p<.01)$. In SRVRT and CR-VRT tests, rate of false answers increased significantly after training $(p<.05)$. Total number of taps and mean inter-tap intervals did not show any difference among weightlifters before and after training $(p>.05)$.

Conclusion: Adolescent weightlifters' executive functions are deteriorated following a training session. In future studies, the duration of this deteriorating effect of strength training can be investigated.

Key words: cognition, executive skill, reaction time, weightlifting, adolescence
Cite this article as: Yargic MP, Aydin L, Erdagi K, Kiziltan E. Cognitive Deterioration Following Strength Training In Adolescents. Selcuk Med J 2020;36(3): 252-258
Disclosure: None of the authors has a financial interest in any of the products, devices, or drugs mentioned in this article. The research was not sponsored by an outside organization. All authors have agreed to allow full access to the primary data and to allow the journal to review the data if requested. 


\section{INTRODUCTION}

Recently, engaging in adequate amounts of physical activity is recommended to youth, not only for its metabolic and cardiovascular benefits but also for the cognitive outcomes. Cognition is a comprehensive definition including many executive functions such as perception, memory, judgement, imagination, thinking, reasoning and attention regulation(1). It is important in goal-directed behavior and is associated with prefrontal cortex activity. Attention regulation is the capability of selectively attending to specific stimuli, inhibiting prepotent responses, and monitoring actions. Attention regulation starts developing in earlier ages and is a determinant of academic achievement (2). A positive relationship between physical activity and academic performance was shown in adolescents (3). High aerobic fitness in preadolescence and adolescence is associated with better relational memory task performance, better performance at activating and adapting neural processes involved in cognitive control to meet and maintain task goals, a more flexible modulation of cognitive control processes $(4,5)$. Besides that, being physically active in youth is associated with preserved cognitive abilities later in life (6).

However, in addition to the studies that advocate the positive effects of exercise on cognitive functions (7), several meta-analysis studies reported that cognitive functions were negatively affected during exercise, and cognitive skills changed slightly after moderate exercise $(8,9)$. While the cognitive effects of exercise were examined, exercise type and intensity were emphasized as important factors. Even an inverted U-shaped relation between the intensity of exercise and cognitive functions had been described in the literature (10). These results are supported with the studies that relates decision making process with increased cortisol level in athletic training (11). Increased corticosteroids enhance emotional interference and susceptibility to interference therefore, impairs selective attention (12).

Studies have demonstrated that regular aerobic exercise improves several aspects of cognition such as attention, executive functions, memory and processing speed $(6,13,14)$. Although studies on exercise and cognition are mainly focused on moderate to vigorous aerobic exercise, Harveson et al. (15) have shown that an acute bout of resistance exercise have improved measures of cognition in high school students as well. Studies on resistance training's effects on cognition are mostly performed with elderly and indicated cognitive improvements (16). Nevertheless, comparing the results of different studies in this area is quite difficult due to differences of exercise protocols in terms of duration and intensity, and due to differences of the tests used to measure cognitive functions. It is not clear how elitelevel resistance training affects cognitive function during adolescence. Elite weightlifters were chosen purposefully, while weightlifting doesn't involve any training components to improve simple reaction times, choice making or any other executive functions. The aim of this study was to determine how a single session of strength training affects cognition in highly trained adolescents.

\section{PATIENTS AND METHODS}

This study was approved by Local Ethics Committee (Project number: 2018/1584). Written informed consents were obtained from all individual participants and legal representatives of the minors prior to the initiation of the study. The study conforms with The Code of Ethics of the World Medical Association (Declaration of Helsinki).

\section{Procedure}

Twenty-five elite female weightlifters were included in the study. This study evaluates motor functions via finger tapping test, ability of sustaining attention via simple and complex visual reaction time tests; and executive functions (sustaining, suppressing and switching attention capabilities) via simple and complex recognition visual reaction time tests. Appropriate tests were applied to the weightlifters twice; first, during rest, and second, immediately after the end of the training. Tests were performed with at least 24 hours of time interval in between, in order to eliminate the learning effect (17). In order to evaluate the immediate effects of a single session training on motor function and cognition in elite weightlifters, resting data of weightlifters were compared with the data obtained after training. In 2019, twenty-five elite female weightlifters were included in the study.

\section{Participants}

Female right-handed adolescent weightlifters who have been training regularly for at least 4 years and competed at national and/or international level participated in the research. Exclusion criteria of the athlete group were color blindness, having slept less than 5 hours the night before tests (18), having consumed any cigarettes, alcohol or energy drinks on the test day $(19,20)$, having consumed more than 1 
Table 1: Demographic characteristics of weightlifters $(n=25)$.

\begin{tabular}{llc}
\hline & Mean & $\begin{array}{c}\text { Standard } \\
\text { Deviation }\end{array}$ \\
\hline Age (years) & 16.4 & 1.63 \\
Height $(\mathrm{m})$ & 1.6 & 0.07 \\
Weight $(\mathrm{kg})$ & 58.7 & 12.5 \\
Body mass index $\left(\mathrm{kg} / \mathrm{m}^{2}\right)$ & 22.6 & 3.65 \\
\hline
\end{tabular}

cup of coffee or two cups of tea on the test day (21), using medication that effects attention or alertness, being diagnosed with attention deficit hyperactivity disorder (22). Demographic characteristics of the participants are demonstrated in Table 1.

\section{Assessment of hand preference}

To assess hand preference, all subjects received a Turkish translation of Edinburgh Inventory. The inventory consists of 10 questions. The questions in the inventory were scored as $-10,-5,0,+5,+10$, respectively. Total Geschwind scores between -100/40 were considered left-handed, between -35/35 were considered both-handed and scores between +40/+100 were considered right-handed (23-25).

\section{Assessment of color blindness}

Color blindness was tested via "Ishihara test for Color blindness". Cards in the Ishihara booklet were shown to participants from $70 \mathrm{~cm}$, for 3 seconds in a room illuminated with a 200-250 lux light bulb and they were instructed to read the numbers on the cards. Participants who make 4 or more mistakes were considered color-blind and were excluded from the study (26).

\section{Finger Tapping Test}

Finger-tapping test (FTT) was performed using the TanTong Finger-Tapping test battery, which was previously described in literature (27). Test was performed in a silent room where participants were seated with their forearms resting on a table in front of a computer keyboard and were instructed to press the key defined on the keyboard " 1 " with the right hand index finger as soon as they feel ready, and press the key repeatedly as quickly and consistently as possible, until the preset time of 20 seconds has elapsed (28). Number of total taps, total time and time difference between successive taps (inter-tap interval) were recorded by the system.

\section{Visual Reaction Time Tests}

Visual Reaction Time (VRT) test modules of the TanTong finger tapping test battery were used.
Four tests, namely, Simple Visual Reaction Time (S-VRT), Complex Visual Reaction Time (C-VRT), Simple Recognition Visual Reaction Time (SR-VRT), Complex Recognition Visual Reaction Time (CRVRT), were performed in order to evaluate ability of sustaining attention and executive functions. In each test, 10 color frames of $7 \times 7 \mathrm{~cm}$ in size presented on computer screen and participant was asked to press the predefined key as soon as possible when she sees the frame. In S-VRT test, the same frame is displayed on the computer screen at fixed intervals. In C-VRT test, the same frame appeared on the screen at variable intervals. The interval was determined randomly by the system and was 4 seconds at maximum. In S-VRT and C-VRT tests, the participant was asked to press predefined key "1" as quickly as possible when frame appears on the screen.

In SR-VRT test, frames of different colors appear on the computer screen at fixed intervals; whereas in CR-VRT test, frames of different colors appear on the screen at variable intervals. In SR-VRT and CR-VRT tests, the participant was asked to press predefined key " 1 " if frame is the color of red and press "2" if not red as quickly as possible. Number of correct and false answers and reaction time were recorded by the system for further analysis.

\section{Training session}

Maximum snatch and clean \& jerk loads were recorded in a training session accompanied by the athletes' coaches, one week prior to study. Weightlifting training session of the athletes included snatch, clean\& jerk, front full squat and snatch drop movements. Training session lasted approximately 90 minutes (15-minute warm-up; 4 sets of 2 repetitions of snatch with $75 \%$ of 1 repetition maximum (RM) followed by 1 set, 1 repetition with RM; 6 sets of twice power clean and 1 jerk with $80 \% \mathrm{RM}$; followed by 1 set, 1 repetition with RM; 6 sets of 2 repetitions of front full squat with $\% 90 \mathrm{RM} ; 6$ sets of 4 repetitions snatch drop with \%70 RM of snatch; 10-minute cool-down and stretching). Mean maximum load athletes could snatch and clean \& jerk were $63.24 \mathrm{~kg}( \pm 15.8 \mathrm{~kg})$ and $78 \mathrm{~kg}( \pm 21.03 \mathrm{~kg})$, respectively. Total relative strength of the weightlifters is calculated as (maximum snatch load + maximum clean \& jerk load)/ body weight (29). The athletes' median total relative strength was calculated as 2.71 (IQR:0.812).

\section{Statistical analysis}

Normality of the data distribution was tested by density plots, histograms and Shapiro-Wilk test. Descriptive statistics were used to analyze the 


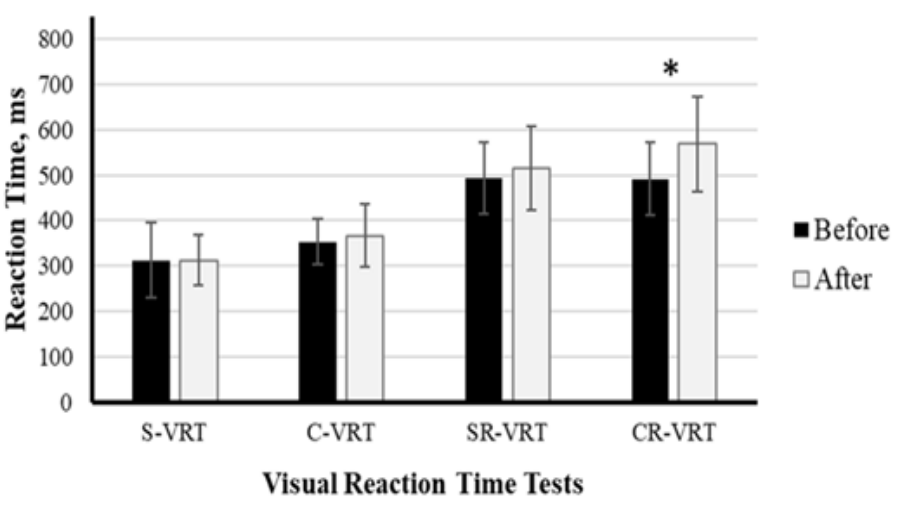

Figure 1. Graphical presentation of the visual reaction times measured with four different tests. Error bars indicate standard deviation. ${ }^{*} p<.01$

demographic characteristics of participants. Student's $t$ test and Wilcoxon signed rank test were used for inferential analyses. The level of significance was set at $p<.05$. All analyses were performed using $R$ software, version 3.5.1 (30).

\section{RESULTS}

Tapping performances are given in Table 2 as number of taps and mean inter-tapping intervals. Total number of taps in 20 seconds and mean intertap intervals did not show any significant difference in the weightlifters group before and after training $(t(22)=-1.40, p=.17 ; t(22)=-0.21, p=.83$; respectively).

Reaction times to four different tests are given in Table 3 and presented graphically in Figure 1. Mean visual reaction times of weightlifters were compared before and after training. Paired samples t test results showed a significant increase in mean CR-VRT of weightlifters after training $(t(22)=-3.45, p<.01)$. Although mean S-VRT, C-VRT and SR-VRT increased after training as well, no statistical significance was

Table 2. Finger tapping task results of weightlifters before and after training.

\begin{tabular}{lcc}
\hline & $\begin{array}{c}\text { Before } \\
\text { Training }\end{array}$ & $\begin{array}{c}\text { After } \\
\text { Training }\end{array}$ \\
\hline $\begin{array}{l}\text { Number of taps } \\
\text { Mean Inter-Tapping }\end{array}$ & $109.1 \pm 9.01$ & $109.7 \pm 8.89$ \\
Interval (ms) & $180.7 \pm 13.89$ & $181.4 \pm 15.68$ \\
\hline
\end{tabular}

Table 3. Mean visual reaction times of participants in milliseconds. Values that have a normal distribution are presented as "mean \pm standard deviation". Non-normally distributed data is displayed as "median (interquartile range)". *Significantly different from CR-VRT before training $(p<.01)$.

\begin{tabular}{lll}
\hline & Before Training & After Training \\
\hline S-VRT & $301.4(67.20)$ & $312.2 \pm 55.96$ \\
C-VRT & $340.1(45.09)$ & $366.6 \pm 69.59$ \\
SR-VRT & $485.7(82.17)$ & $515.8 \pm 92.47$ \\
CR-VRT & $491.9 \pm 80.55$ & $568.3 \pm 104.23^{*}$
\end{tabular}

S-VRT: Simple visual reaction time, C-VRT: complex recognition visual reaction time,

SR-VRT: Simple recognition visual reaction time, CR-VRT: complex recognition visual reaction time

observed in these comparisons $(V=144, p=.86$; $V=140, p=.96 ; V=92, p=.16$, respectively).

Beside the reaction times, the accuracy of the answers in CR-VRT and SR-VRT data were also analyzed and the results are given in Table 4. Wilcoxon signed rank sum analysis displayed that both in SRVRT and CR-VRT tests, the number of false answers increased significantly immediately after training compared to resting values $(V=225, p<.01 ; V=209$, $p=.03$, respectively).

\section{DISCUSSION}

FTT is a widely used test in order to evaluate the state of voluntary repetitive motor functions $(28,31$ 33). Studies which simply compare the tapping rate of athletes from different disciplines and engaged different levels of training, to non-athletes showed no statistically significant difference $(34,35)$. In this respect, our FTT results were in accordance with the literature. In our study, we observed that reaction times were prolonged as VRT tests became more difficult. We associated the prolongation of VRT times without

Table 4. Percentage of correct answers to SR-VRT and CR-VRT tasks. *Significantly different from SRVRT before training $p<.01{ }^{* *}$ Significantly different from CR-VRT before training $p=.03$

\begin{tabular}{lcc}
\hline & Before Training & After Training \\
\hline SR-VRT & $99.1 \%$ & $96.9 \%^{*}$ \\
CR-VRT & $94.3 \%$ & $91.4 \%^{* *}$ \\
\hline
\end{tabular}

SR-VRT: Simple recognition visual reaction time, CR-VRT: complex recognition visual reaction time 
any difference in FTT results with the complexity of VRT tests without any prominent deterioration in motor skills. This is also important as it demonstrates the consistency of the test modules used. Stuss et al. have categorized the tasks that are related to attentional system as sustaining, concentrating, sharing, suppressing, switching, preparing and setting attention. Suppressing attention is required when automatic responses need to be inhibited and switching attention demands shifting attention between tasks requiring different stimulus-response pairings (36). A single session of weightlifting training prolonged CR-VRT and increased the number of false answers, namely impaired suppressing and switching attention, without affecting motor function or the ability to sustain attention, which may be caused by influences on higher brain centers. In other words, weightlifting training impairs the executive functions of female adolescent right after the session without affecting the capability of sustaining attention. There is a consensus on that moderate aerobic exercise positively affects cognitive functions. However, contradictory results on the effects of high intensity exercise have been reported. Even an inverted $U$-shaped relation between the intensity of physical exercise and cognitive functions had been described. Davey et al defined two cut-off intensity values for exercising with bicycle ergometer each in either side for optimum mental benefit (mainly short-term memory); one is in the sub-maximal side which starts causing better cognitive function and the other in severe physical exertion side which triggers deterioration in mental performance (10).

On the other hand, a more recent study reported that acute bicycle ergometer exercise improves cognitive performance measured with computerized Stroop test at both moderate and high intensity (37). The studies suggest that intensity and duration of the exercise are as important in resistance training as it is in aerobic training, by means of its effects on cognition (15). Intensity, as well as the duration of the exercise employed in these studies were much lower compared to the weightlifting training session in our study. We may interpret the discrepancy between our results and the others can be explained with the differences in the duration and intensity of the training sessions employed in the respective studies. Therefore, further studies are still needed to determine the optimum intensity and duration of strength training for immediate cognitive benefits. Although study results on the effects of resistance exercise among adolescents' and young adults' executive skills are diverse, the cognitive benefits of resistance exercise among elderly are more pronounced in the literature. Elderly benefit from both moderate and high-intensity resistance training and cognitive improvements are thought to be mediated by IGF-1 (insulin-like growth factor 1) $(38,39)$. The cognitive benefits of resistance exercise are more evident when subjects have cognitive impairment at baseline, for example, cognitive decline due to aging, Alzheimer's disease or Parkinson's disease $(40,41)$. More sensitive tests might reveal smaller differences in executive skills of adolescents. Although benefits of resistance training during youth are not evident by means of executive skills, it may help preventing cognitive decline in later life, this assumption however, requires further studies (6).

A limitation of our study participants are only females, which limits making sex-based comparisons. Menstrual cycle of the participants was not taken into consideration in this study, because menstrual cycle's effect on cognitive functions is very small and clinically not relevant, however it has pronounced effects on emotion processing (42). In the literature executive functions are categorized as "cool" and "hot", cool executive functions describes the psychological process involves pure logic and critical analysis, whereas hot is psychological process driven by emotion (43). This approach emphasizes the influence of emotions on decision-making. The tests that we used do not analyze emotion-related aspects of decision-making process. Therefore, menstruation cycle should not affect the results. Finally, our study design doesn't allow us to make a statement related to the mechanism. However, it is important in terms of guiding or complementing further studies that may be useful in explaining possible mechanisms.

\section{CONCLUSION}

In this study, a single session of strength training impaired executive functions of highly-trained adolescents without affecting motor function or the ability to sustain attention. Further research can determine an optimum duration and intensity of resistance exercise for cognitive benefits and reveal how long the immediate deteriorating effect of weightlifting training on executive functions last.

Conflict of interest: Authors declare that there is no conflict of interest between the authors of the article. 
Financial conflict of interest: Authors declare that they did not receive any financial support in this study.

Address correspondence to: Melda Pelin Yargic, Necmettin Erbakan University, Meram Faculty of Medicine, Department of Sports Medicine, Konya, Turkey

e-mail: meldapelin@gmail.com

Phone: +905076069586

\section{REFERENCES}

1. Miller EK, Cohen JD. An integrative theory of prefrontal cortex function. Annu Rev Neurosci 2001;24:167-202.

2. Berthelsen D, Hayes N, White SLJ, et al. Executive function in adolescence: Associations with child and family risk factors and self-regulation in early childhood. Front Psychol 2017;8:903.

3. Esteban-Cornejo I, Tejero-Gonzalez CM, Sallis JF, et al. Physical activity and cognition in adolescents: A systematic review. J Sci Med Sport 2015;18:534-9.

4. Chaddock L, Erickson KI, Prakash RS, et al. A functional MRI investigation of the association between childhood aerobic fitness and neurocognitive control. Biol Psychol 2012;89:2608.

5. Pontifex MB, Raine LB, Johnson CR, et al. Cardiorespiratory fitness and the flexible modulation of cognitive control in preadolescent children. J Cogn Neurosci 2011;23:1332-45.

6. Hötting K, Röder B. Beneficial effects of physical exercise on neuroplasticity and cognition. Neurosci Biobehav Rev 2013;37:2243-57.

7. Hillman $\mathrm{CH}$, Erickson $\mathrm{KI}$, Kramer AF. Be smart, exercise your heart: Exercise effects on brain and cognition. Nat Rev Neurosci 2008;9:58-65.

8. Donnelly JE, Hillman $\mathrm{CH}$, Castelli D, et al. Physical activity, fitness, cognitive function, and academic achievement in children. Med Sci Sport Exerc 2016;48:1197-222.

9. Fedewa AL, Ahn S. The effects of physical activity and physical fitness on children's achievement and cognitive outcomes. Res Q Exerc Sport 2011;82:521-35.

10. Davey CP. Physical exertion and mental performance. Ergonomics 1973;16:595-9.

11. Smilios I, Pilianidis $T$, Karamouzis $M$, et al. Hormonal responses after various resistance exercise protocols. Med Sci Sport Exerc 2003;35:644-54.

12. Henckens MJAG, van Wingen GA, Joëls $M$, et al. Timedependent effects of cortisol on selective attention and emotional interference: A functional MRI study. Front Integr Neurosci 2012;6:66.

13. Smith PJ, Blumenthal JA, Hoffman BM, et al. Aerobic exercise and neurocognitive performance: A meta-analytic review of randomized controlled trials. Psychosom Med 2010;72:23952.

14. Pontifex MB, McGowan AL, Chandler MC, et al. A primer on investigating the after effects of acute bouts of physical activity on cognition. Psychol Sport Exerc 2019;40:1-22.

15. Harveson AT, Hannon JC, Brusseau TA, et al. Acute effects of 30 minutes resistance and aerobic exercise on cognition in a high school sample. Res Q Exerc Sport 2016;87:214-20.

16. Smolarek AH, Ferreira LP, Mascarenhas $L$, et al. The effects of strength training on cognitive performance in elderly women. Clin Interv Aging 2016;11:749.

17. Philip P, Sagaspe P, Prague M, et al. Acute versus chronic partial sleep deprivation in middle-aged people: Differential effect on performance and sleepiness. Sleep 2012;35:9971002.

18. Landauer AA, Howat PA. Alcohol and the cognitive aspects of choice reaction time. Psychopharmacology (Berl) 1982;78:296-7.

19. Afshan A, Bhutkar MV, Reddy R, et al. Effect of chronic cigarette smoking on intraocular pressure and audio-visual reaction time. Int J Biol Med Res 2012;3:1760-3.

20. Smith AP, Christopher G, Sutherland D. Acute effects of caffeine on attention: A comparison of non-consumers and withdrawn consumers. J Psychopharmacol 2013;27:77-83.

21. Bolfer C, Casella EB, Baldo MVC, et al. Reaction time assessment in children with ADHD. Arq Neuropsiquiatr 2010;68:282-6.

22. Hotermans C, Peigneux $P$, Maertens de Noordhout A, et al. Early boost and slow consolidation in motor skill learning. Learn Mem 2006;13:580-3.

23. Oldfield RC. The assessment and analysis of handedness: The Edinburgh inventory. Neuropsychologia 1971;9:97-113.

24. Geschwind N, Behan P. Left-handedness: Association with immune disease, migraine, and developmental learning disorder. Proc Natl Acad Sci U S A 1982;79:5097-100.

25. Tan Ü. The distribution of the geschwind scores to familial left-handedness. Int J Neurosci 1988;42:85-105.

26. Hardy LH, Rand G, Rittler MC. Tests for the detection and analysis of color-blindness I the Ishihara test: An evaluation. J Opt Soc Am 1945;35:268.

27. Kızıltan E, Barut Ç, Gelir E. A High-Precision, Low cost system for evaluating finger-tapping tasks. Int J Neurosci 2006;116:1471-80.

28. Aydin L, Kiziltan E, Gundogan NU. Polyphasic temporal behavior of finger-tapping performance: A measure of motor skills and fatigue. J Mot Behav 2016;48:72-8.

29. Ebadai KA-R. Relative strength, body mass and height as predictors of olympic weightlifting players performance. Selçuk Üniversitesi Beden Eğitimi ve Spor Bilim Derg 2011;13

30. Leijnse JNAL, Campbell-Kyureghyan NH, Spektor D, et al. Assessment of individual finger muscle activity in the extensor digitorum communis by surface EMG. J Neurophysiol 2008; 100:3225-35.

31. Hunt T, Ferrera M, Miller $L$, et al. The effect of effort on baseline neuropsychological test scores in high school football athletes. Arch Clin Neuropsychol 2007;22:615-21.

32. Malinauskas R, Dumciene A, Mamkus G, et al. Personality traits and exercise capacity in male athletes and nonathletes. Percept Mot Skills 2014;118:145-61.

33. Stuss DT, Alexander MP, Shallice T, et al. Multiple frontal systems controlling response speed. Neuropsychologia 2005;43:396-417.

34. Dupuy O, Billaut F, Raymond F, et al. Effect of acute intermittent exercise on cognitive flexibility: The role of exercise intensity. J Cogn Enhanc 2018;2:146-56.

35. Grassmann V, Thomatieli RV, Santos D. The impact of resistance exercise on the cognitive function of the elderly. Med Sci Sport Exerc 2007;39:1401-7.

36. Liu-Ambrose T, Donaldson MG. Exercise and cognition in older adults: Is there a role for resistance training programmes? Br J Sports Med 2009;43:25-7.

37. Balsamo S, Willardson JM, Frederico $S$ de $S$, et al. Effectiveness of exercise on cognitive impairment and 
Alzheimer's disease. Int J Gen Med 2013;6:387-91.

38. Tanaka K, Quadros AC de, Santos RF, et al. Benefits of physical exercise on executive functions in older people with Parkinson's disease. Brain Cogn 2009;69:435-41.
39. Sundström-Poromaa I. The menstrual cycle influences emotion but has limited effect on cognitive function. Vitam Horm 2018;107:349-76.

40. Poon K. Hot and cool executive functions in adolescence: Development and contributions to important developmental outcomes. Front Psychol 2017;8:2311. 